\title{
Developing Countries and the WTO Doha Round: Market Access, Rules and Differential Treatment
}

\author{
Bernard Hoekman \\ World Bank and CEPR
}

\begin{abstract}
This paper discusses the challenges confronting developing countries seeking to use WTO negotiations to promote their economic growth and performance. Progress will require that major stakeholders within countries perceive the overall package to be beneficial. A number of possible focal points that could be used as benchmarks for negotiations are discussed, as is the issue of differential and more favorable treatment for developing countries. A precondition for a good development outcome is a significant reduction in barriers to trade in goods and services. This will have a much greater beneficial impact than efforts at multilateral rule-making in regulatory areas. A new approach towards special and differential treatment that involves greater differentiation between members and is based on country-specific economic analysis and criteria would help to enhance the development-relevance of the WTO.
\end{abstract}

- JEL Classifications: F13, F35, O19

- Key words: Trade policy, Economic development, Trade negotiations, WTO

\section{Introduction}

The November 2001 "Doha Development Agenda" puts development concerns at the core of WTO deliberations. The challenge is to achieve an outcome that supports poverty reduction and economic growth. The implementation problems associated with a number of WTO agreements, the addition of disciplines on

\footnotetext{
*Corresponding address: Bernard Hoekman, 1818 H ST. NW Washington DC 20433, Tel: 1202473 1185, Fax: 1202522 1159, E-mail: BHOEKMAN@WORLDBANK.ORG

(C)2004-Center for International Economics, Sejong Institution, All Rights Reserved.
} 
intellectual property protection (TRIPS), and the persistence of tariff peaks and production and export subsidies for agricultural commodities in the OECD has led to a 'development credibility' deficit for the WTO. A precondition for the Doha round to generate a good outcome from a development perspective is that the system becomes more balanced and has greater support of domestic stakeholders in developing countries.

Developing countries have historically played only a minor role in the multilateral trading system. Until the Uruguay Round (1986-93), their participation was à la carte, with many not making commitments. This changed with the entry into force of the WTO in 1995. Because of the so-called Single Undertaking, developing countries became subject to most of the disciplines of the many agreements contained in the WTO (albeit after transition periods had expired). At the same time, a number of the agreements increasingly came to be seen as having little benefit. In the case of some agreements (TRIPS) the perception rapidly emerged that benefits were highly skewed towards rich countries (Finger, 2002). The resulting 'Uruguay Round hangover' led to a great deal of skepticism regarding the benefits of WTO membership. Many governments and civil society of developing countries view the prospect of additional agreements and disciplines in the WTO with great suspicion. The Uruguay Round hangover has made them very aware of the downside of signing on to agreements that are ill understood and that have little if any backing by domestic stakeholders. Indeed, many developing countries are now actively seeking to improve their terms of trade in the WTO.

However, industrialized countries appear to be less enthused about active multilateral engagement. Industry in OECD countries already operates in an environment where much of what they trade is duty free (due to duty drawback and similar schemes, regional trade agreements and past negotiations that reduced MFN tariffs on their products substantially). And, other interest groups have come to the fore that would like to introduce binding disciplines on non-trade policies such as labor standards and environmental regulation into the WTO, and more generally, seek to move the WTO behind the border.

Developing country governments confront a three-fold challenge: inducing major trading partners to improve market access; ensuring that any multilateral trade rules support economic development; and convincing domestic stakeholders that there are significant net positive payoffs from further domestic trade reforms that are locked in via the WTO. Much of the burden of rebalancing the trading system to support economic development more effectively lies with developing 
countries. They are the major demandeurs and have the greatest stake in using the system to help them to adopt better domestic policies.

Success will require both reciprocity and increased attention to subjecting rulemaking to economic cost-benefit analysis. The WTO process involves giving export interests that want better market access an incentive to put pressure on import-competing sectors to concede opening of the home market. With the spread of regional integration agreements and duty-free treatment provisions for imports used in export production, many multinationals now have less incentive to invest resources in support of traditional merchandise trade liberalization. As a result, reciprocity must be sought increasingly in other areas such as services and domestic regulatory policy commitments. The latter are more complex to negotiate. Negotiations to lower tariffs require little oversight from civil society as the outcome is generally welfare improving. When it comes to domestic regulation it is not easy - and perhaps impossible - to trade 'concessions'. The practice to date has been to focus instead on the identification of specific rules that should be adopted by all - usually 'good practices' that have emerged over time in OECD countries. While these may be beneficial, adoption of such rules predominately impose implementation costs on developing countries (Finger and Schuler, 2000). The challenge here is to ensure that multilateral rules support development and to recognize that one size does not necessarily fit all.

\section{A. The Trade Agenda at the National Level}

Success in integrating into the world economy is far from universal. In part this reflects continued anti-export biases created by border trade policies and the absence of an enabling environment for supply-side responses to changed incentives to emerge. Behind the border barriers to trade integration - for example, lack of access to finance, high cost and low quality distribution and transport services - are often important. To benefit from liberalization, measures to lower trade-related transactions costs and regulatory reforms may be called for to ensure that economic responses to liberalization are efficient, equitable and enduring. Priorities will differ depending on country circumstances. In some lowincome economies priority areas for action are to strengthen institutions such as customs, reduce transport costs and ensuring that export marketing and product standards are satisfied. In others, reducing tariffs and other trade barriers remain a priority. Table 1 provides a summary illustrative matrix mapping types of countries against possible priority areas. 
Table 1. Illustration of possible national priorities in different types of countries

\begin{tabular}{|c|c|c|c|c|}
\hline \multirow[t]{2}{*}{ Country type } & \multicolumn{2}{|c|}{ Traditional trade policies } & \multicolumn{2}{|c|}{ Behind the border trade policies } \\
\hline & Policy & Institutions & Policy & Institutions \\
\hline $\begin{array}{l}\text { Low income: } \\
\text { weak institutions, } \\
\text { high fiscal } \\
\text { dependence on } \\
\text { tariffs }\end{array}$ & $\begin{array}{l}\text { Reduce tariff } \\
\text { dispersion; } \\
\text { develop } \\
\text { domestic tax bases }\end{array}$ & $\begin{array}{l}\text { Strengthen } \\
\text { customs; consider } \\
\text { free trade zones as } \\
\text { s catalyst for exports }\end{array}$ & $\begin{array}{l}\text { Enhance efficiency of } \\
\text { transport and transit } \\
\text { regimes; maintain } \\
\text { s competitive real } \\
\text { exchange rate }\end{array}$ & $\begin{array}{l}\text { Strengthen national } \\
\text { capacity to design trade } \\
\text { and regulatory policies; } \\
\text { Upgrade product } \\
\text { standards bodies }\end{array}$ \\
\hline $\begin{array}{l}\text { Low income: } \\
\text { strong role of the } \\
\text { State, high } \\
\text { protection; high } \\
\text { transactions costs }\end{array}$ & $\begin{array}{l}\text { Reduce border } \\
\text { barriers } \\
\text { significantly; } \\
\text { reduce tariff } \\
\text { dispersion }\end{array}$ & $\begin{array}{l}\text { Reduce red tape; } \\
\text { adopt drawback or } \\
\text { temporary } \\
\text { admission customs } \\
\text { schemes }\end{array}$ & $\begin{array}{l}\text { Promote competition } \\
\text { in service industries, } \\
\text { including through } \\
\text { FDI and privatization }\end{array}$ & $\begin{array}{l}\text { Strengthen standards } \\
\text { setting and certification } \\
\text { bodies. Efficient } \\
\text { regulation to achieve } \\
\text { social objectives }\end{array}$ \\
\hline & $\begin{array}{l}\text { Maintain } \\
\text { relatively low } \\
\text { and uniform } \\
\text { tariffs }\end{array}$ & $\begin{array}{l}\text { Develop customs } \\
\text { and related } \\
\text { infrastructure }\end{array}$ & $\begin{array}{l}\text { Develop legal and } \\
\text { regulatory regimes } \\
\text { for services }\end{array}$ & $\begin{array}{l}\text { Develop national } \\
\text { capacity to } \\
\text { design/enforce } \\
\text { regulatory policies }\end{array}$ \\
\hline $\begin{array}{l}\text { Middle income, } \\
\text { small, low } \\
\text { average protection }\end{array}$ & $\begin{array}{l}\text { Lower tariff } \\
\text { peaks }\end{array}$ & $\begin{array}{l}\text { Adopt ex post } \\
\text { controls to } \\
\text { facilitate trade }\end{array}$ & $\begin{array}{l}\text { Enhance technology } \\
\text { and E-commerce- } \\
\text { related policies }\end{array}$ & $\begin{array}{l}\text { Strengthen enforcement } \\
\text { of prudential regulation }\end{array}$ \\
\hline $\begin{array}{l}\text { Middle income, } \\
\text { large, high } \\
\text { protection }\end{array}$ & $\begin{array}{l}\text { Reduce average } \\
\text { and dispersion } \\
\text { of protection }\end{array}$ & $\begin{array}{l}\text { Reduce red tape; } \\
\text { implement trade } \\
\text { facilitation } \\
\text { measures }\end{array}$ & $\begin{array}{l}\text { Services } \\
\text { liberalization; end } \\
\text { monopolies; develop } \\
\text { competition policy }\end{array}$ & $\begin{array}{l}\text { Pro-competitive and } \\
\text { prudential regulation; } \\
\text { establish competition } \\
\text { authorities }\end{array}$ \\
\hline
\end{tabular}

Source: Hoekman (2002).

\section{Border barriers}

Despite significant liberalization by many developing countries, traditional trade policies continue to imply significant anti-export biases in a number of regions, most notably South Asia. Average (unweighted) tariffs in the Middle East and sub-Saharan Africa are in the 20 percent range (Table 2). However, the border agenda" in many low-income countries is more institutional than trade policy related. Although non-tariff barriers have come down substantially in most developing countries (Table 3), inefficiencies in public administration are often an impediment to trade. Customs clearance and logistics related transactions costs can be a major disincentive for investment in tradable sectors, especially in activities that are time sensitive or where it is important to be integrated into global production networks that operate on the basis of just-in-time supply chain management. Exporters must have access to imported intermediate inputs at world market prices in order to be competitive. In countries where tariffs continue to be needed for revenue mobilization this requires well-functioning customs regimes 
Table 2. Average Unweighted Tariff Rates By Region

\begin{tabular}{lccccc}
\hline Region & $\mathbf{1 9 7 8 - 8 0}$ & $\mathbf{1 9 8 1 - 8 5}$ & $\mathbf{1 9 8 6 - 9 0}$ & $\mathbf{1 9 9 1 - 9 5}$ & $\mathbf{1 9 9 6 - 9 9}$ \\
\hline Africa & 38.2 & 29.3 & 26.9 & 22.3 & 17.8 \\
East Asia & 23.5 & 26.9 & 20.7 & 14.6 & 10.4 \\
Latin America & 28.1 & 26.4 & 24.1 & 13.9 & 11.1 \\
MENA (ex-OPEC) & 29.6 & 24.6 & 24.1 & 22.9 & 19.3 \\
South Asia & $\mathrm{NA}$ & 71.9 & 69.8 & 38.9 & 30.7 \\
Europe/Central Asia & 12.0 & 21.6 & 14.9 & 8.1 & 10.1 \\
Industrial economies & 11.9 & 8.9 & 8.2 & 6.8 & 6.1 \\
\hline
\end{tabular}

Table 3. Frequency of core NTBs in developing countries, 1989-98

\begin{tabular}{lcc}
\hline \multicolumn{1}{c}{ Country } & $\mathbf{1 9 8 9 - 9 4}$ & $\mathbf{1 9 9 5 - 9 8}$ \\
\hline East Asia and the Pacific (7) & $\%$ & $\%$ \\
Latin America and the Caribbean (13) & 30.1 & 16.3 \\
Middle East and North Africa (4) & 18.3 & 8.0 \\
South Asia (4) & 43.8 & 16.6 \\
Sub-Saharan Africa (12) & 57.0 & 58.3 \\
\hline
\end{tabular}

Note: Parentheses indicate the number of countries per region for which data are available.

Source: World Bank.

that refund taxes paid on imported inputs, or, preferably, allow exporters to import inputs duty free (so-called temporary admission or green channel treatment). Many countries do not have well-functioning drawback regimes, creating antiexport bias.

The 'behind the border' trade agenda

A supporting legal and regulatory environment is vital for sustained growth. While this goes far beyond trade-related policy, elements of the associated 'behind the border' trade agenda include policies and institutions that support the ability of national firms to compete internationally. Meeting international standards for quality, health and safety is increasingly a precondition for contesting international markets. Many low-income countries are not adequately equipped to deal with rapidly tightening product standards and labeling requirements and confront major investment requirements in order to do so (Henson et al. 2001; Wilson, 2002). The same is true of services. Reducing the cost of services that affect trade can easily have economy-wide welfare benefits that are a multiple of those associated with merchandise liberalization, and, indeed, may be a precondition for benefiting from such liberalization. 
Initiatives to strengthen private and public service institutions that support trade - access to credit, modernization of product standards conformity assessment systems - and to reduce the cost of key inputs (transport, telecoms, insurance, finance, etc.) should be pursued in the context of an overall national strategic framework that identifies where the payoff to reform and public investment is largest. Careful policy analysis is needed to identify both priorities and options for reform. In many cases pro-competitive reforms will be needed, as greater competition (contestability of markets) will reduce prices and increase the variety of goods and services. Whatever the priorities are, in all countries there is a need for complementary macroeconomic, education, health, and social policies. Separating out the trade agenda from the development agenda more broadly defined is difficult, if not impossible. The key need is to integrate trade into the national development strategy. This is also necessary to be able to make an informed assessment if and how issues should be addressed in the WTO.

The premise in what follows is that priority should be given to a 'traditional' market access agenda that focuses on the reciprocal reduction of barriers to trade in all products - goods and services - that is, including agriculture and laborintensive manufactures such as apparel. There is still great scope to use traditional reciprocity dynamics to reduce barriers to trade and that is where the positive impact on development is likely to be the greatest.

\section{B. Improving Market Access}

A great deal of research has documented that there is still a large market accessrelated agenda (Anderson et al, 2001; World Bank, 2001). The extent to which developing and industrialized country trade barriers are lowered, tariff peaks and escalation removed, export subsidies eliminated and production subsidies replaced with less trade distorting measures will define to an important extent the development relevance of WTO talks.

Most-favored-nation (MFN) tariff rates of developed countries are less than 5 percent on average. Indeed, much trade is now duty-free as a result of zero ratings, preferences and free trade agreements. However, tariffs for some commodities are over 100 percent (Hoekman, Ng and Olarreaga, 2002). Such tariff peaks-rates above 15 percent - are often concentrated in products that are of interest to developing countries. In 1999, in the US alone, imports originating in leastdeveloped countries (LDC)s generated tariff revenue of $\$ 487$ million, equal to $11.6 \%$ of the value of their exports to the US, and $15.7 \%$ of dutiable imports (US 
Department of Commerce, 1999). ${ }^{1}$ Protection in OECD countries currently imposes costs on developing countries that exceed official development assistance flows (some $\$ 45$ billion per year). Benefits to developing countries from abolishing their own protection are over $\$ 60$ billion. Global protection of trade in merchandise costs the world economy some $\$ 250$ billion (Hertel and Martin, 2000). If current policies restricting trade in services are considered, the figure can easily double or triple (Stern, 2002). Add in the trade chilling effect of instruments of contingent protection (antidumping, safeguards) - see below - and the real income gains from elimination of redundant red tape at borders and it is clear that the benefits of reducing market access barriers are large.

Because average tariff barriers in developing countries are higher than in industrialized nations, much of the potential welfare gains from reducing trade barriers will arise from own liberalization. The large potential payoff from reciprocal tariff liberalization provides a strong rationale for developing countries to engage in traditional GATT-type tariff negotiations - greater efficiency in home markets and cheaper access to imports will be complemented by better access to export markets. This argument applies to LDCs as well. As noted by Winters (1999), a useful mnemonic in this connection is WYDIWYG: what you do is what you get. When it comes to trade policy, the payoffs to negotiations and liberalization are primarily a function of domestic action - the extent to which own protection is reduced. ${ }^{2}$ Three sectors matter greatly for developing countries: agriculture, textiles and clothing and services.

\section{Agriculture}

Despite the fact that the inclusion of agricultural policy disciplines in the Uruguay Round has justifiably been hailed as a major achievement, it must be recognized that the primary effect of the Uruguay Round was simply to bring agriculture back into the trading system. The commitments that were made - the ban on quantitative restrictions, the resulting tariffication of border protection in this sector, the minimum market access commitments implemented through tariff rate quotas, the agreement to lower export subsidies and reduce the aggregate

\footnotetext{
'This calculation excludes Angola, 95\% of whose exports are oil-related and not dutiable. The LDCs comprise 49 low-income countries, mostly in Africa.

${ }^{2}$ Fiscal constraints may imply that low-income countries need to maintain tariffs above the average prevailing in more advanced economies for revenue collection purposes. In such cases, countries should consider greatly reducing the dispersion in duty rates by moving towards a uniform tariff (Tarr, 2002).
} 
measure of support (AMS) - did not do much to lower agricultural protection. The effective level of protection has diminished little since the conclusion of the Uruguay Round in 1995.

Total net transfers from consumers and taxpayers to farmers in OECD countries equaled 76 percent of the farm gross value added in 1986-88; in 2000, after implementation of all Uruguay commitments, they still amounted to 62 percent of gross value added. Although the producer nominal protection coefficient (the ratio of prices received by producers to the border price) fell from 58 to 35 percent between 1986-88 and 1999-2001 in the OECD, the number of active farmers declined over this period as well. As a result, support per farmer has continued to rise in many OECD countries - by 31 percent in the U.S. and 60 percent in the EC (Anderson, 2003; Messerlin, 2002).

Highly distorting agricultural support policies in many OECD countries has a major detrimental effect on developing countries, including LDCs. Indeed, 18 percent of LDC exports on average comprise goods that are subsidized in at least one WTO member, compared to 3-4 percent for other countries (Table 4). A similar observation holds for imports - nine percent of LDC imports involve products that are subsidized, compared to 3-4 percent for other countries. Numerous analyses have documented the detrimental effects of OECD policies on developing countries. For example, sugar is one of the most policy-distorted of all commodities, with OECD protection rates frequently above 200 percent (Mitchell, 2003). Producers in those countries receive more than double the world market price. OECD support to sugar producers of $\$ 6.4$ billion per year roughly equals developing country exports. US subsidies to cotton growers totaled $\$ 3.9$ billion last year, three times US foreign aid to Africa. These subsidies depress world cotton prices by around 10 percent, cutting the income of poor farmers in West Africa, Central and South Asia, and poor countries around the world. In West

Table 4. Trade Shares of Products Affected by Agricultural Subsidies (1995-98, percent)

\begin{tabular}{lcccc}
\hline & \multicolumn{2}{c}{ Domestic Support } & \multicolumn{2}{c}{ Export Subsidies } \\
\cline { 2 - 5 } \multicolumn{1}{c}{ Country } & $\begin{array}{c}\text { Exports } \\
1995-98 \text { ave }\end{array}$ & $\begin{array}{c}\text { Imports } \\
1995-98 \text { ave }\end{array}$ & $\begin{array}{c}\text { Exports } \\
1995-98 \text { ave }\end{array}$ & $\begin{array}{c}\text { Imports } \\
1995-98 \text { ave }\end{array}$ \\
\hline All countries (143) & 3.6 & 3.7 & 4.4 & 4.4 \\
Industrial Countries (23) & 3.1 & 3.3 & 4.0 & 3.9 \\
Developing Countries (90) & 4.2 & 4.2 & 5.0 & 5.0 \\
Least Dev. Countries (30) & 17.8 & 8.9 & 16.7 & 13.1 \\
\hline
\end{tabular}

Source: Hoekman, Ng and Olarreaga (2003). 
Africa alone, where cotton is a critical cash crop for many small-scale and nearsubsistence farmers, annual income losses for cotton growers are about $\$ 250$ million a year (Baffes, 2003).

The Doha call for elimination of agricultural export subsidies is clearly of great importance for developing countries that have a comparative advantage in the products affected, both directly and indirectly. While attaining this objective will undoubtedly be difficult, the benchmark is clear and is a good one. The primary need is to establish a deadline to achieve it. Matters are more difficult when it comes to other subsidies. In principle, de-coupling domestic support payments from production makes sense. Given that there is a rationale for subsidies in many contexts and that the revealed preference of many governments is to use subsidies, it would appear more effective to focus on reduction of border barriers and the abolition of explicit export subsidies. This would automatically impose serious constraints on the feasibility of production subsidies by greatly increasing their costs (Snape, 1987).

From a trade perspective, reducing border barriers is critical. Hoekman, $\mathrm{Ng}$ and Olarreaga (2003) find that a 50 percent global tariff cut will have a much greater positive effect on exports and welfare of developing countries than a 50 percent cut in subsidies, even if the analysis is limited to the set of commodities that are currently subsidized by at least one WTO member. The reason for this is that tariffs are often very high for subsidized products, frequently taking the form of non-transparent specific duties. While minimum market access commitments negotiated during the Uruguay Round - implemented through tariff rate quotas (TRQs) - ensure some access, in many cases the TRQs are small, and the effect of the tariffs is to support high domestic price levels.

This does not imply that negotiations can neglect domestic support policies. Most developing countries oppose further agricultural trade liberalization in an environment that is characterized by continued large-scale support for OECD farmers. Past experience has demonstrated that the gains from own liberalization are attenuated because of the market segmenting effect of OECD subsidy policies. Indeed, own liberalization in some instances - e.g., India - has proven to be politically unsustainable as farmers are subjected to large world price swings and import surges of subsidized commodities (Gulati and Narayanan, 2002). Substantial reduction in OECD agricultural support policies is therefore not just important for developing countries in its own right - in that it generates direct benefits for the many economies that are (potential) net exporters - but is critical 
from a political economy perspective. It is necessary to create the conditions to allow developing country governments to pursue domestic reforms. That is, subsidy reforms in OECD countries are necessary, although not sufficient, for developing countries to maximize the gains from the current WTO negotiations on agriculture, as this will require own liberalization.

Also important are effective safeguard mechanisms. Safeguards are often the only available instrument to developing country governments to respond to OECD intervention that leads to import surges and periods of low priced imports. In the absence of effective safeguard mechanisms that can be invoked when import surges harm domestic farmers, many countries will not want to substantially reduce tariff bindings for agricultural products (as high levels of bound tariffs allows governments to raise applied rates unilaterally if deemed necessary up to level of the tariff binding). Large differences between the level of a tariff binding and the applied tariff rate creates uncertainty and reduces the relevance of GATT rules. While bringing bound rates down towards applied rates is beneficial and should be an objective, linking such a process to the removal of export subsidies; decoupling of domestic support and substantial reductions in OECD tariff peaks can help ensure that such reforms are implemented.

\section{Textiles and Clothing and Contingent Protection}

Although the WTO Agreement on Textiles and Clothing requires the abolition of all textile quotas by January 1, 2005, tariff barriers to trade in this sector remain high. As important is the uncertainty of access generated by the threat of contingent protection (safeguards and especially antidumping). Antidumping has become a frequently used instrument in both industrialized and developing countries. Not only have developing countries become frequent users of antidumping, but on a per dollar of import coverage basis they are the most intensive users of antidumping (Table 5).

The existence of antidumping induces rent-seeking behavior on the part of import-competing firms, and creates substantial uncertainty regarding the conditions of market access facing exporters. Investigations have a chilling effect on imports (they are a signal to importers to diversify away from targeted suppliers) and are often facilitating devices for the conclusion of market sharing or pricefixing agreements with affected exporters (see Bloningen and Prusa 2002 for a survey of the evidence). The best policy in this regard has been known for a long time - abolish the instrument. Safeguards are a better and more honest 
Table 5. Antidumping Initiations Per US Dollar of Imports 1995-99

\begin{tabular}{lcc}
\hline \multirow{2}{*}{$\begin{array}{c}\text { Country/Economy } \\
\text { Initiating }\end{array}$} & \multicolumn{2}{c}{ Against All Economies } \\
\cline { 2 - 3 } & $\begin{array}{c}\text { No. of Antidumping } \\
\text { Initiations }\end{array}$ & $\begin{array}{c}\text { Initiations per US dollar of imports } \\
\text { Index (USA=100) }\end{array}$ \\
\hline Argentina & 89 & 2125 \\
South Africa & 89 & 2014 \\
Peru & 21 & 1634 \\
India & 83 & 1382 \\
New Zealand & 28 & 1292 \\
Venezuela & 22 & 1174 \\
Australia & 89 & 941 \\
Colombia & 15 & 659 \\
Brazil & 56 & 596 \\
Israel & 19 & 418 \\
Chile & 10 & 376 \\
Indonesia & 20 & 330 \\
Mexico & 46 & 290 \\
Turkey & 14 & 204 \\
Korea & 37 & 185 \\
Canada & 50 & 172 \\
European Union & 160 & 130 \\
United States & 136 & 100 \\
Malaysia & 11 & 97 \\
\hline
\end{tabular}

Source: Finger, Ng, and Wangchuk (2001).

instrument to address the problem antidumping is used for - providing importcompeting industries with time to adjust to increased foreign competition (Finger, 1996). Greater discipline on the use of the instrument could involve determining the impact on the economy of imposing duties through so-called public interest clauses - current legislation and WTO rules only impose weak procedural disciplines on import-competing industries and do not give users of imports a voice. The problem is a political economy one: a necessary condition for reform is greater mobilization of countervailing forces in the domestic political arena.

\section{Services}

There is a huge market access agenda in services trade, one that spans foreign direct investment as well as cross-border trade, and where to date only limited progress has been made in the WTO (Mattoo, 2001). ${ }^{3}$ Here again the greatest 
gains to developing countries would come from reforming their own policies. In contrast to tariffs, services trade and investment restrictions do not generate revenue for the government. Instead, they tend to raise costs for users, imposing a tax on the whole economy. ${ }^{4}$

Market access and regulation are closely intertwined. Services are activities where there is often need for some type of regulation to address market failures or achieve social (noneconomic) objectives. A good case can be made that many of the 'backbone' services that are critical to development - transport, energy, telecoms, finance - increasingly have become industries where network externalities are important. Regulation to ensure that markets are contestable needs to focus not only on 'traditional' types of entry barriers - outright bans, licensing, etc. - but on the ability to connect to the network at a reasonable price, apply the relevant technologies, etc. Designing and enforcing policies to achieve this is not trivial. In many cases, regulatory thinking and economic analysis is still evolving rapidly when it comes to network industries, and technological developments may make specific types of interventions redundant or counterproductive. Careful assessments of the implications of alternative types of international cooperation - which may be regional rather than multilateral - are required to determine what options might be most appropriate for developing countries.

\section{Market Access Focal Points and Negotiating Modalities}

Many countries have proposed the use of tariff-cutting formulae to reduce tariffs on merchandise trade - both manufactures and agricultural. This is a good approach, especially if a non-linear formula is used that reduces high tariffs (peaks) much more than low tariffs. The request-offer approach used in the Uruguay Round can easily increase the variance in protection, gives greater negotiating leverage to large countries and allows peaks to remain in place. A Swiss type formula, as proposed by the Chair of the WTO market access committee, is much preferable. ${ }^{5}$ However, it is important that at the same time

\footnotetext{
${ }^{3}$ Walmsley and Winters (2002) estimate the global gains from allowing temporary entry of both skilled and unskilled labor services equivalent to $3 \%$ of the current workforce in OECD countries would be some 11/2 times greater than the gains from merchandise liberalization.

${ }^{4}$ Stern (2002) surveys the literature.

${ }^{5}$ The formula approach that was suggested by the Chair in May 2003 is an augmented Swiss formula that
} 
WTO members also agree on an end point or final objective. A Swiss type of formula can greatly reduce the average level of protection and the dispersion of tariff rates, but ideally needs to be complemented by a decision that the end point or ultimate objective should be the complete removal of tariffs on goods that are of export interest to developing countries. Given that average OECD rates for manufactures are already low, a possible focal point here would be the complete elimination of tariffs by these countries by 2015 - the target date for the achievement of the Millennium Development Goals.

Given that OECD countries have already bound virtually all their tariff lines at applied rates, any formula that gives weight to both additional bindings (increases in the ratio of the number of bound to unbound lines) and reductions in the absolute difference between bound and applied rates, will automatically give credit for past reforms to developing countries in terms of attaining an agreed target level of liberalization. What this implies is that formulae need to focus on bound rates and not exclusively on applied tariff rates.

The efficiency of the service sector is a major determinant of competitiveness (most services are inputs into production). Services are therefore of great importance to developing countries and there are substantial opportunities both to expand exports and to liberalize further access to developing country markets. While the latter will bring the greatest gains, opening by developed countries of temporary access to service markets for natural service providers - so-called mode 4 of the GATS - and a binding of the current liberal policy set that is applied to crossborder trade (modes 1 and 2 of the GATS) - would both be valuable and assist governments in pursuing domestic reforms. Opening of developed country labor markets to allow temporary entry by foreign workers equal to 3 percent of the current workforce would generate welfare (real income) gains that exceed those

makes the cut in tariffs a function of the initial average level of protection. It is defined as: $T_{1}=B \times$ NAV $\mathrm{x} \mathrm{T}_{0} /\left(\mathrm{B} \times \mathrm{NAV}+\mathrm{T}_{0}\right.$ ), where $\mathrm{T}_{1}$ is the final (bound) tariff; $\mathrm{B}$ is a parameter to be chosen; NAV is the initial national average tariff; and $\mathrm{T}_{0}$ is the initial (bound) tariff. The proposal is that all countries bind at least $95 \%$ of all tariff lines and value of imports. The factor B x NAV equals the maximum coefficient of the Swiss formula used in the Tokyo Round. The Chair also proposed that specific tariffs be converted into ad valorem equivalents, that tariffs in sectors of interest to developing countries be reduced to zero (on a reciprocal basis); that developing countries have a transition period that is three times longer than for developed countries; and that LDCs be exempted from tariff cuts altogether. While in principle a good approach, LDCs should consider participating in the tariff cutting and binding processnot participating removes an opportunity to further reduce anti-export bias and the dispersion in rates of protection. 
that could be attained from full merchandise trade liberalization (Walmsley and Winters, 2002). In addition, many developing countries have begun to exploit the opportunities offered by the internet and telecommunication networks to provide services through cross-border trade. Currently such trade is largely free of restrictions, and this desirable state of affairs should be locked in through the GATS.

Given that there are only limited sector-specific commitments on national treatment and market access in the GATS, the simplest benchmark would pertain to the sectoral coverage ratio and/or the number of sectors where no restrictions on national treatment and market access are maintained (Hoekman and Kostecki, 2001). For many developing countries the coverage of specific commitments is well below 25 percent of all services and modes of supply. Binding the status quo would help reduce uncertainty, while pre-committing to future reform can help increase the relevance of the GATS. Given the importance of movement of natural services providers as a mode of contesting foreign service markets for developing countries, explicit quantitative targets for 'mode 4' visas could be considered - for example, a minimum share of total service sector employment (Walmsley and Winters, 2002). Even if not used as the focal point for negotiations, this can be a metric for judging the outcome of negotiations.

The terms of a potential deal could involve mode 3 concessions by developing countries - made on a case-by-case basis - against comprehensive mode 1 and mode 4 commitments on the part of developed countries that are made on the basis of a 'formula' (model schedule or template) (Mattoo, 2002). While national concessions on mode 3 should be sensitive to the type of service - in particular the need for complementary regulation - developing countries have a lot to gain from both dimensions: making own mode 3 commitments will help improve economic performance and expand employment; the same dynamics are generated as a result of better access to services markets through modes 1 and 4 .

\section{Reciprocal MFN Liberalization and Unilateral Trade Preferences}

Historically, the strategy of developing countries in the GATT/WTO has been to limit the reach of reciprocity by seeking 'differential and more favorable treatment'. Special and differential treatment (SDT) provisions in the WTO span three core areas: market access, through trade preferences granted to developing countries and acceptance that developing countries make fewer market access commitments than developed countries in trade negotiations; exemptions or deferrals from some 
WTO rules; and technical assistance to help implement WTO mandates. Only the second of these is legally enforceable - preferences and technical assistance are so-called best endeavors commitments. There is general dissatisfaction with SDT provisions among both developed and developing countries as the current system has not worked especially well. SDT is a major agenda item for the Doha round. What follows discusses preferences; the next Section turns to the issue of the scope of WTO rules.

A major factor affecting negotiating modalities on market access is that developing countries have been granted preferential access to rich country markets. This raises the question whether market access preferences should be deepened and extended as opposed to an effort that centers on MFN liberalization on a reciprocal basis. It also raises the question of what to do about the erosion of preferences that is unavoidable given further MFN-based liberalization. For many products exported by low-income countries, tariffs in high-income countries may be zero as a result of trade preference schemes. The EU Everything But Arms (EBA) initiative and the US African Growth and Opportunity Act (AGOA), in particular, offer deep preferences to beneficiary countries that can satisfy eligibility constraints.

Trade preferences for many developing countries tend to be limited for tariff peak items as these are by definition 'sensitive' products that are often excluded or subject to some type of quantitative limitation. Much of the economic literature concludes that preferences do little good, and may even do harm (Hoekman, Michalopoulos and Winters, 2003; World Bank, 2003). Reasons for this include:

(i) Countries benefiting from preferential access are subject to rules of origin. These may be so strict (constraining) that countries are forced to pay the MFN tariff because they cannot satisfy the requirements. Research reveals that utilization rates are often much less than 100 percent (Brenton, 2003; Inama, 2002);

(ii) Often goods in which developing countries have a comparative advantage are the most sensitive products that have the highest tariffs. Preferences for these products are frequently limited;

(iii) Preferences are uncertain, subject to unilateral change or withdrawal, and to non-trade conditionality (satisfaction of labor rights, environmental requirements, etc.);

(iv) Preferences can give rise to serious trade diversion as the set of goods that 
beneficiary developing countries produce and trade will tend to overlap with other developing countries that are not beneficiaries.

(v) Even in cases where preferences have value that is, they apply to highly protected sectors in donor countries and thus generate rents in practice these rents will not accrue completely to the recipient country. Instead, a share of the rents, perhaps most of them, will be captured by importers (distributors, retailers).

(vi) Fears of preference erosion may spur efforts to maintain preference margins, in the process impeding both multilateral liberalization efforts and own reforms by recipient countries.

There is an acute danger that substantial progress on market access through a formula approach will be impeded because of concerns by countries that this will erode the value of their current preferential access. The danger is that this may give scope to preference-granting countries to delay implementing tariff reductions for products that are important for other developing countries (and their own welfare). The same is true for agricultural subsidies. Some developing countries are indirectly benefiting from OECD domestic support because they have preferential access to the protected market - the EC sugar regime is an example. The preferences therefore potentially create incentives for an 'unholy alliance' with OECD farm interests, at the cost of less global liberalization.

One way forward would be to agree on a single preferential tariff rate - zero for all products currently benefiting from GSP status in developed countries (as is the case presently in the US), thereby removing all partial preferences. However, extending preferential duty-free access to large countries such as India and China will be very difficult politically. A major reason why duty-free access for much of Africa and the LDCs could be implemented is that these countries account for less than 0.5 percent of world trade. Given the political reality that developed nations will not grant larger developing countries unconditional preferential market access, and that this is not first best in the first place - given the benefits of own reforms - this will have to occur through reciprocal, MFN liberalization.

In order to assist low-income developing countries to benefit from market access opportunities a significant increase is needed in technical and financial assistance to expand supply capacity and improve the investment climate in low income countries. The need for this is acute in absolute terms, but is made even stronger as the trading system moves in the direction of lower MFN trade barriers and the consequent erosion of preferences for those countries that currently benefit 
from effective preferential access. One option that could be considered as an alternative to maintaining preference margins is for OECD countries to help current developing country beneficiaries adjust through direct income support-type instruments (targeted at affected farmers and firms and decoupled from past production levels). More generally, what is required is assistance to help affected countries deal with the associated adjustment costs by supporting diversification into other activities, retraining, and so forth.

\section{WTO Rules and Special and Differential Treatment}

A precondition for developing countries to benefit from WTO membership is 'getting the rules right' - ensuring that they support development. Most developing countries are latecomers to the multilateral trading system - a fact that explains why many present WTO rules predominantly reflect the interests of rich countries and the status quo disciplines that already have been put in place by them. Thus, the much greater latitude that exists in the WTO for the use of agricultural subsidization, for example, reflects the use of such support policies in many developed countries. The same is true for the permissive approach that has historically been taken towards the use of import quotas on textile products - in principle prohibited by GATT rules. More recently, the inclusion of rules on the protection of intellectual property rights has strengthened perceptions that the WTO contract is unbalanced.

The Single Undertaking approach in the Uruguay Round led to the inclusion into the WTO of rules in many areas of a regulatory nature. This was the culmination of a process started in the Tokyo Round (1973-9). It shows few signs of abating - witness the focus on competition law, FDI policy, transparency in government procurement, trade facilitation and environmental policy. Calls for deeper integration at the multilateral level range from coordinated application of national policies to the harmonization of regulatory regimes. A key question from a development perspective is to determine the rationale for proposals to pursue deeper integration, and, if so, whether the WTO is the appropriate forum for this.

'Getting the rules right' requires evaluating and understanding the implications of alternative rules. This is not straightforward, especially when it comes to the regulatory, behind-the-border policies that are increasingly the subject of multilateral discussions. Too often deliberations in the WTO are not informed by economic analysis or a good understanding of the costs and benefits of specific proposals or rules, or how these costs and benefits are distributed across or within 
countries.

One consequence of this is reflected in the substantial effort that has been expended over the years to provide 'special and differential treatment' (SDT) for developing countries in the WTO (Hudec, 1987; Finger, 1991). A good case can be made that efforts to enhance the development relevance of the WTO need to distinguish the issue of SDT - the principle that poorer countries should be granted "better than MFN" treatment - from the broader issue of ensuring that WTO rules and disciplines support development. The second dimension is by far more important. This goes well beyond the specific language that is found in WTO agreements relating to developing country interests. Instead, it revolves around whether a particular WTO rule makes sense for developing countries to implement (Hoekman, Michalopoulos and Winters, 2003).

The Doha Ministerial Declaration reaffirmed the importance of SDT by stating that 'provisions for special and differential treatment are an integral part of the WTO agreements'. It called for a review of WTO SDT provisions with the objective of "strengthening them and making them more precise, effective and operational" [para. 44]. The Declaration also states that "modalities for further commitments, including provisions for special and differential treatment, be established no later than 31 March 2003 [para. 14]. However, in the event efforts in 2002 to come to agreement on ways to strengthen and operationalize SDT provisions have not been successful so far. Looking forward, the experience with Uruguay Round implementation and the Doha discussions on SDT in 2002-3 suggest a new approach is needed.

\section{Recognizing differential interests and capacities}

As noted previously, the primary challenge from a development perspective is to get the rules 'right'. This requires engagement by developing country stakeholders and economic analysis of the implications of proposed rules at the national level. Given the resource and skill constraints that prevail in many countries, this is indeed a huge challenge. One way of recognizing these constraints is through SDT provisions that give countries the assurance that rules will only apply once a nation has put in place the preconditions needed to benefit from implementation. Even if countries consider a set of rules to be in their interest, other issues may constitute a more urgent priority for investment of scarce administrative and financial resources. These observations suggest the need for "differentiation" among developing countries in determining the reach of WTO 
rules. The need for this is greatest for "resource-intensive" disciplines, that is, those that require significant complementary legal, administrative, and institutional investments or capacity; or that will potentially give rise to large net transfers out of developing countries (as could be the case under the TRIPS agreement, for example).

The basic rationale for differentiation is that certain agreements or rules simply may not be immediate development priorities and/or require that other preconditions be satisfied for implementation to be beneficial. These preconditions can be proxied by the attainment of a minimum level of per capita income, institutional capacity, or economic scale. Some WTO disciplines may not be appropriate for very small countries in that the regulatory institutions that are required may be unduly costly - that is, countries may lack the scale needed for benefits to exceed implementation costs. ${ }^{6}$

Several options could be considered to take into account and operationalize country differences in WTO agreements. Such "rule-related SDT" could involve:

- Adopting a rule of thumb that makes a group of countries eligible to 'opt-out' of provisions that entail substantial implementation costs until such time as they have passed certain economic development-related benchmarks or eligibility criteria. This would imply revisiting the current set of country groups recognized in the WTO: the LDCs (a UN defined group); other developing countries (a selfdesignated group), and developed countries. It would also require agreement as to which WTO disciplines this SDT would apply to;

- An agreement-specific approach involving country-based criteria that are applied on an agreement-by-agreement basis to determine whether (when) agreements should be implemented. This could be linked to the provision of technical assistance and development of a national action plan for ultimately assuming the WTO obligations concerned;

- A country-based approach that places trade reforms priorities in the context of national development plans such as the PRSP, and would employ multilateral

\footnotetext{
${ }^{6}$ For example, despite remarkable reductions in customs clearance times that have been achieved by some LDCs (sometimes from weeks to days or hours, as in Senegal), the customs regimes in many participating countries are characterized by long clearance times, a plethora of informal fees and inadequate performance monitoring indicators. Many countries are struggling to implement the Agreement on Customs Valuation and to work with and reform other institutions whose actions impinge on customs efficiency such as security and enforcement.

${ }^{7}$ These options are discussed further in Stevens (2002), Prowse (2002), Wang and Winters (1999), and Hoekman, Michalopoulos and Winters (2003).
} 
surveillance and monitoring to establish a cooperative framework under which countries are assisted in gradually adopting WTO norms as part of a more general program of trade-related reforms.

A common feature of these options is that they entail more narrowly defining eligibility for temporary exemptions from WTO rules and devoting much more attention to determining the economic costs and benefits of implementation of rules. None of the options will be easy to operationalize. Country classification inevitably creates tensions among different developing countries as to which countries would be counted in and which out. What constitutes "resourceintensive", for example, and the extent to which specific agreements will give rise to large implementation costs are questions that will require analysis, both general and country-specific. Countries or analysts may disagree about the magnitude of assessed costs and benefits. Determining criteria that could be used in the implementation context will require input from stakeholders, government agencies and development institutions. While this could help to strengthen the coherence of policy at both the national and international levels, it would also make the WTO negotiation and enforcement process much more complex.

Widening the set of actors involved in implementation of a new approach towards SDT may reduce the risk of inducing countries to adopt and pursue a program of trade and regulatory reform that may not in fact be suited to the country concerned. However, care would need to be taken to ensure that this would not lead to cross-conditionality. Many countries were concerned in the Uruguay Round about avoiding possible "cross-conditionality" between WTO and international financial institutions; this led to a ministerial declaration on "coherence" to call for "avoiding the imposition on governments of crossconditionality or additional conditions" resulting from cooperation between the WTO and the international financial institutions. ${ }^{8}$

Several options may therefore be feasible in recognizing country differences in the ability to benefit from implementation of resource-intensive rules. The choice of type of approach requires considerable thought and discussion. Arguably, what matters most at this point is that WTO members recognize that capacities and priorities differ hugely across the membership and consider alternative approaches along the lines sketched out above. Given the steady expansion of the WTO into regulatory areas, this would help make 'development relevance' more than a

${ }^{8}$ Declaration on the Contribution of the World Trade Organization to Achieving Greater Coherence in Global Economic Policymaking, December 15, 1993. 
slogan. A new approach towards SDT that is anchored much more solidly on economic analysis and a national process of identification of development priorities could do much to enhance the 'ownership' of the institution in developing countries. Whatever is done, it is important that transparency and predictability is preserved, to avoid wasteful strategic behavior and to target SDT to those countries that are most in need of it. In determining SDT eligibility, non-negotiability once a deal has been reached is critical.

A first step could be to establish a broad-based, high-level group operating under the auspices of the WTO General Council to explore different options, possible mechanisms and details of an alternative approach, including establishing criteria to determine which rules are resource-intensive in implementation, with recommendations to be made before the end of the Doha Round. The terms of reference of such a working group should be relatively broad and include both national economic policymakers and representatives of the international development community.

\section{Conclusion}

The challenges confronting developing countries seeking to expand their international trade are primarily domestic. Necessary conditions are an open domestic trade regime, a supportive investment climate and a host of complementary policies relating to education, health, infrastructure, etc. The WTO negotiating agenda often will have little bearing on the priority issues and needs that must be addressed on the ground in developing countries. The primary beneficial role that the WTO can play is to foster the reduction of barriers to trade - in goods and services - on a reciprocal basis. As far as multilateral policy disciplines are concerned, a precondition for benefits to result is to get the rules 'right' - ensure that they support development. Getting 'the rules right' requires analysis and participation by stakeholders. One size may not fit all, especially when it comes to the regulatory, 'behind-the-border' policies.

Historically, the strategy of developing countries has been to seek SDT: unilateral trade preferences from developed countries, rejection of reciprocity in the exchange of market access commitments; and exemptions or deferrals from some WTO rules. Preferences have not proven to be very effective as an instrument of development. They often come laden with restrictions, product exclusions, and administrative rules that prevent beneficiaries from utilizing them fully. Even when effective, 
they divert trade away from equally poor but excluded developing countries. Irrespective of trade diversion costs, preferences do little to help most of the world's poor, as they live in countries such as India and China that are granted only limited preferences, if any, for products in which they have a comparative advantage.

Multilateral nondiscriminatory liberalization of trade in the goods and services in which many developing countries tend have a comparative advantage is a more effective and efficient approach to expand trade opportunities. This should include a binding commitment by developed countries to abolish export subsidies and decouple agricultural support policies. The pursuit of these objectives would be more supportive of development than one that continues to emphasize preferential access to markets and non-reciprocity. This is both because own liberalization is beneficial and because a nondiscriminatory approach would result in reduction in barriers to trade maintained by middle income as well as developed countries. The former are increasingly important potential markets, and have been among the most dynamic traders in recent years (World Bank, 2003).

As far as WTO rules are concerned, especially new rules on 'behind-the-border' policies, the priority is to ensure that any negotiated disciplines support development and are seen to do so in developing countries. This is a critical pre-condition for 'ownership' of WTO agreements. However, even good agreements may not be a priority for some countries, especially the poorest and smallest, nor are the benefits likely to be proportional in all countries. The experience after the Uruguay Round with implementation of agreements by developing countries has demonstrated that limiting recognition of differential capacities and levels of development to uniform transition periods and non-binding offers of technical assistance is inadequate. Adopting a new approach to SDT that is firmly grounded on economic analysis that reflects national circumstances would do much to enhance the development-relevance of the WTO.

Development assistance must play an important role in helping to expand and improve the trade capacity that is needed for countries to benefit from better access to markets. Policy reforms and trade-related investment needs should be determined on a country-by-country basis as part of the national processes used by governments to identify priorities. Technical and financial assistance should be driven by national considerations, not by the WTO agenda. However, additional assistance will be needed to help low-income countries adapt to a gradual reduction in trade preferences following further nondiscriminatory trade liberalization, and to assist poor net importing countries to deal with the potential detrimental effects of a 
significant increase in world food prices should these materialize. Major commitments were made by both developed and developing countries in Monterrey in $2002-$ the priority now is to identify the policy measures seen by developing-country governments as urgent areas for action and to address the associated resource needs.

\section{Acknowledgements}

Thanks are due to Carsten Fink, Will Martin, Aaditya Mattoo, and Marcelo Olarreaga for helpful comments and suggestions on an earlier draft and to Francis $\mathrm{Ng}$ for data. This paper draws in part on joint work in progress with Costas Michalopoulos and Alan Winters. The views expressed are personal and should not be attributed to the World Bank.

Received 7 August 2003, Accepted 29 January 2004

\section{References}

Anderson, Kym. (2003) "How can agricultural trade reform reduce poverty?" Background paper prepared for the U.N. Millennium Project Task Force on Trade.

Anderson, K., B. Dimaranan, J. Francois, T. Hertel, B. Hoekman and W. Martin (2001), The Cost of Rich (and Poor) Country Protection to Developing Countries, Journal of African Economies 10(3): 227-57.

Baffes, J. (2003) "Cotton Market Policies: Issues and Facts," World Bank, mimeo.

Bloningen, B. and T. Prusa. 2001. Antidumping, NBER Working Paper 8398.

Brenton. P. and M. Manchin. 2002. Making EU Trade Agreements Work: The Role of Rules of Origin, CEPS Working Document 183 (Brussels).

Finger, J. M. (1996) Legalized Backsliding: Safeguard Provisions in the GATT, in W. Martin and A. Winters (eds.) The Uruguay Round and the Developing Economies (Cambridge: Cambridge University Press).

Finger, J. M. (2002) "The Doha Agenda and Development: A View From the Uruguay Round," Manila: Asian Development Bank.

Finger, J. M. and P. Schuler. (2000) "Implementation of Uruguay Round Commitments: The Development Challenge" The World Economy, 23:511-26.

Finger, J.M., F. Ng, and S. Wangchuk. (2000) “Antidumping as Safeguard Policy,” World Bank, mimeo.

Fink, C. A. Mattoo and I. Neagu. (2001) "Trade in International Maritime Services: How Much Does Policy Matter?," Policy Research Working Paper 2522, World Bank (www.worldbank.org/trade). 
Francois, J.F. and W. Martin (2003), Formula Approaches for Market Access Negotiations, The World Economy 26(1): 1-28, January.

Gulati, Ashok and Sudha Narayanan. (2002) "Managing Import Competition When Developing Countries Liberalize Trade: The Indian Experience," IFPRI, mimeo.

Hertel, T. and W. Martin. 2000. "Liberalizing Agriculture and Manufactures in a Millennium Round: Implications for Developing Countries," The World Economy, 23:455-70.

Henson, S., K. Preibisch, O. Masakure. (2001) "Review of Developing Country Needs and Involvement in International Standards-Setting Bodies" (www.dfid.gov.uk).

Hoekman, Bernard. (2002) "Strengthening the Global Trade Architecture for Development: The Post-Doha Agenda," World Trade Review, 1: 23-46.

Hoekman, B. and M. Kostecki. (2001) The Political Economy of the World Trading System: The WTO and Beyond. Second Edition. Oxford: Oxford University Press.

Hoekman, B., C. Michalopoulos and L. Alan Winters. (2003) More Favorable and Differential Treatment of Developing Countries: Towards a New Approach in the WTO," World Bank, mimeo.

Hoekman, B. F. Ng and M. Olarreaga. (2002) Tariff Peaks in the Quad and Least Developed Country Exports, World Bank Economic Review 16:1-22.

Hoekman, B. F. Ng and M. Olarreaga. (2003) "Reducing Agricultural Tariffs versus Domestic Support: Whats More Important for Developing Countries?," mimeo.

Inama, Stefano. (2003) "Trade Preferences and the WTO Negotiations on Market Access," UNCTAD, mimeo.

Mattoo, Aaditya. (2001) "Liberalizing Trade in Services," World Bank, mimeo (www. worldbank.org/trade).

Mattoo, Arvind, Devesh Roy and Arvind Subramanian. (2002) "The Africa Growth and Opportunity Act and its Rules of Origin: Generosity Undermined?," Policy Research Working Paper 2908, World Bank.

Messerlin, P. (2003) "Agriculture in the Doha Agenda," Policy Research Working Paper 3009, World Bank.

Prowse, Susan. (2002) "The Role of International and National Agencies in Trade-Related Capacity Building," World Economy 25(9): 1235-1261.

Snape, Richard (1987) The Importance of Frontier Barriers, in Henryk Kierzkowski (ed.), Protection and Competition in International Trade (London: Basil Blackwell).

Stern, R. (2002) "Quantifying Barriers to Trade in Services," in B. Hoekman, P. English and A. Mattoo (eds.), Development, Trade and the WTO: A Handbook, Washington: World Bank.

Stevens, Christopher. (2002) "The Future of SDT for Developing Countries in the WTO," Institute for Development Studies, Sussex, mimeo (May).

Tarr, D. (2002) "Arguments for and Against Uniform Tariffs," in B. Hoekman, P. English and A. Mattoo (eds.), Development, Trade and the WTO: A Handbook, Washington: World Bank.

UNCTAD. (2001) Duty and Quota Free Market Access for LDCs: An Analysis of Quad Initiatives. Geneva: UNCTAD. 
United States Department of Commerce. 1999. US Merchandise Trade: Selected Highlights. Washington DC: US Government Printing Office.

Walmsley, T. and L. A. Winters (2002), "Relaxing Restrictions on Temporary Movement of Natural Persons: A Simulation Analysis," University of Sussex, mimeo.

Wang, Z.K. and L.A. Winters. (2000) "Putting "Humpty" Together Again: Including Developing Countries in a Consensus for the WTO CEPR Policy Paper No. 4.

Wilson, J. S. (2001) "Bridging the Standards Divide: Recommendations for Reform from a Development Perspective," World Bank, mimeo (www.worldbank.org/trade).

Winters, L.A. (1999) "Trade Policy as Development Policy," presented at the UNCTAD $\mathrm{X}$ High-level Round Table on Trade and Development (www.unctad.org).

World Bank. (2001) Global Economic Prospects and the Developing Countries: Making Trade Work for the Worlds Poor. Washington DC: World Bank.

World Bank. (2003) Global Economic Prospects and the Developing Countries: Realizing the Development Promise of the Doha Agenda Washington DC: World Bank. 